\title{
MENINGKAT LIFE-SKILL WARGA BELAJAR MELALUI PELATIHAN KOMPUTER DI PKBM AT-TAJDID KOTA CIMAHI
}

\author{
Zaenal Mutaqin \\ IKIP Siliwangi \\ zaa.mutaa@gmail.com
}

\begin{abstract}
ABSTRAK
Tujuan penelitian ini mengetahui upaya, hasil, faktor pendukung dan penghambat peningkatan life-skills warga belajar melalui pelatihan komputer. Pendekatan penelitian yang digunakan adalah deskriptif kualitatif dengan data diperoleh dari hasil wawancara, observasi, dokumentasi, tes tertulis dan tes praktik. Sumber data penelitian diperoleh dari tutor, warga belajar, dan pengelola. Data dianalisis menggunakan triangulasi sumber, metode, dan teori. Hasil penelitian menunjukkan bahwa upaya tutor dalam meningkatkan keterampilan komputer warga belajar paket $\mathrm{B}$ dan paket $\mathrm{C}$ berjalan dengan baik dan berhasil. Peserta pelatihan mendapatkan hasil dengan memiliki kemampuan kognitif, afektif serta skills yang membantu peserta pelatihan mudah mendapatkan pekerjaan dan memiliki usaha. Faktor pendukung adalah tingginya tingkat kemauan warga belajar, sarana dan prasarana yang memadai, media dan metode pembelajaran yang cukup baik, serta bantuan dana dari APBD yang cukup membantu. Faktor penghambatnya adalah kurangnya perekrutan peserta, komputer yang rusak dan jumlahnya sedikit dibandingkan dengan jumlah peserta pelatihan, terbatasnya bantuan dana alokasi APBD, dan kurangnya jumlah tutor.
\end{abstract}

Kata kunci: pelatihan, komputer, dan pelatihan komputer

\section{PENDAHULUAN}

Pendidikan memegang peran penting dalam pembangunan nasional yang mana melalui pendidikan yang baik, akan terlahir manusia Indonesia yang mampu bersaing di era globalisasi dengan tingginya persaingan dalam semua aspek. Pada zaman era globalisasi yang tinggi ini, maka setiap orang harus dapat memiliki kecakapan hidup (life-skills) yang melekat pada dirinya. Karena kecakapan hidup merupakan suatu upaya pendidikan untuk meningkatkan kapasitas dan kapabilitas setiap warga negara. Kecakapan hidup terbagi menjadi empat jenis yaitu kecakapan personal, akademik, social, dan vokasional.

(Herlinda, Hidayat, \& Djumena, 2017) mengungkap bahwa hasil pelatihan dapat meningkatkan kecakapan hidup yang mencakup kecakapan personal, sosial, akademik, dan vokasional. Adapun pengertian kecakapan hidup menurut (Depdiknas, 2002) adalah kecakapan yang dimiliki seseorang untuk berani menghadapi problema hidup dan kehidupan dengan wajar tanpa merasa tertekan, kemudian secara proaktif dan kreatif mencari serta menemukan solusi sehingga akhirnya mampu mengatasinya. Demikian 
menurut UNESCO dalam (Anwar, 2006) menyampaikan program life-skills berpegang pada empat pilar pembelajaran, yaitu belajar memperoleh pengetahuan (learning to know), belajar untuk bisa berbuat/bekerja (learning to do), belajar menjadi orang yang berguna (learning to be), dan belajar untuk dapat hidup bersama (learning to live together).

Pelaksanaan pembangunan menuntut adanya tenaga kerja yang memiliki keterampilan, kecakapan dalam berbagai kegiatan. Sehingga target yang telah ditetapkan dapat tercapai dengan baik. Dalam hal ini perlu adanya pemberdayaan, pelatihan serta program-program pelatihan yang akan membantu menghadapi permasalahan pada diri manusia yakni memperkuat dan meningkatkan kemampuan dan keterampilan pada diri manusia itu sendiri. Hal ini dijelaskan dalam (Undang-Undang No. 20, 2003) tentang Sistem Pendidikan Nasional, memberikan dasar hukum untuk membangun pendidikan nasional dengan menerapkan prinsip demokrasi, otonomi, keadilan dan menjunjung tinggi hak asasi manusia. Penerapan semua ketentuan dalam Undang-undang ini diharapkan untuk mendukung segala upaya memecahkan masalah pendidikan yang pada gilirannya akan dapat memberikan sumbangan yang signifikan terhadap masalah-masalah makro bangsa Indonesia khususnya terhadap masalah pengangguran.

Pendidikan non-formal sebagai salah satu jalur dalam sistem pendidikan nasional yang memiliki peranan penting dalam memberikan layanan pendidikan bagi masyaraka, karena masyarakat tentunya sangat membutuhkan dan merupakan upaya pemberdayaan masyarakat untuk meningkatkan kemampuan masyarakat agar dapat berkembang sesuai dengan keterampilan yang akan ia miliki. Menurut (Sudjana, 2004, p. 44) Pendidikan Luar Sekolah (PLS) adalah setiap usaha pelayanan pendidikan luar sistem sekolah berlangsung seumur hidup dijalankan dengan sengaja, teratur, dan berencana. yang bertujuan mengaktualisasi potensi manusia (sikap, tindak, dan karya) sehingga dapat terwujud manusia seutuhnya yang gemar belajar dan mampu meningkatkan taraf hidupnya.

Tingkat pengangguran sebagian besar dilatarbelakangi oleh tingkat pendidikan yang hanya berpendidikan Sekolah Dasar (SD) dan Sekolah Menengah Pertama (SMP). Hal ini terjadi pada masyarakat Cikendal, Melong, Kota Cimahi. Terdapat beberapa faktor yang menyebabkan terjadinya pengangguran, yaitu jumlah pencari kerja lebih besar dari pada jumlah kesempatan kerja yang tersedia dan kesenjangan antara kualitas pencari kerja dengan kualifikasi yang dibutuhkan oleh pasar kerja. Faktor tersebut merupakan faktor dominan yang menyebabkan pengangguran. Maka dari itu, untuk mengurangi masalah tersebut perlu adanya penyelenggaraan pendidikan yang sesuai dengan perkembangan jaman di Indonesia sebagai negara berkembang. Kemajuan pendidikan melalui jalur formal maupun non-formal diharapkan akan meningkatkan kemampuan dan keterampilan seseorang.

PKBM At-Tajdid Kota Cimahi telah terlaksana program pelatihan komputer untuk meningkatkan keterampilan life-skills warga belajarnya. Hal yang menjadi alasan PKBM AtTajdid Kota Cimahi melaksanakan program pelatihan komputer tersebut yaitu karena tutor dalam melakukan pembelajaran di kelas kesetaraan paket B dan kesetaraan paket C beradaptasi dengan warga belajar, melakukan pendekatan sehingga dapat melihat dan mengidentifikasikan sebelumnya. Bahwasanya warga belajar di PKBM At-Tajdid Kota Cimahi drop-out sekolah pada jenjang SD dan SMP, sehingga warga belajar tidak 
mempunyai keterampilan komputer. Oleh karenanya menjadikan warga belajar buta dengan teknologi komputer. Bahwa pada zaman sekarang ini teknologi komputerisasi di dunia semakin cangging. Jika setiap orang tidak memiliki keterampilan komputer maka orang tersebut bisa ketinggalan zaman. Maka dari itu pengelola serta tutor bekerjasama untuk menjalankan dan melaksanakan pelatihan komputer, agar dapat meningkatkan dan memberikan bekal keterampilan komputer pada warga belajarnya. Karena di zaman sekarang bukan hanya ilmu pengetahuan saja yang jadi modal dasar untuk mendapatkan pekerjaan, sekarang keterampilan atau life-skills yang dimiliki akan sangat berguna untuk mendapatkan pekerjaan atau membuka usaha secara mandiri.

Program pelatihan komputer di PKBM At-Tajdid Kota Cimahi, tutor sangat berperan penting dalam pelaksanaan kegiatan, karena tutorlah yang melakukan pendekatan sehingga dapat melihat dan mengidentifikasikan sebelumnya bahwasanya warga belajar membutuhkan bekal keterampilan komputer pada dirinya dan tutor juga memotivasi warga belajar untuk mengikuti pelatihan komputer tersebut. Tutorlah yang mengajarkan teori komputer serta praktik menggunakan komputer. Peran pengelola hanya memfasilitasi dan mendukung terlaksananya program pelatihan komputer. Pelatihan sebagai salah satu bentuk penyelenggaraan pendidikan pada jalur pendidikan non-formal, mempunyai kaitan yang sangat erat dengan jalur pendidikan formal. Selain memberikan kesempatan bagi peserta didik yang ingin mengembangkan keterampilan jenis pendidikan tertentu, yang telah ada di jalur pendidikan formal juga memberikan kesempatan bagi masyarakat yang ingin mengembangkan pendidikan keterampilannya yang tidak dapat ditempuh dan tidak terpenuhi pada jalur pendidikan formal. Menurut (Artasasmita, 1985, p. 10) pelatihan adalah suatu kegiatan pendidikan yang dilakukan sengaja, terorganisir dan sistematik untuk memberikan satu mata pelajaran atau rangkaian pelajaran tertentu pada orang dewasa atau remaja tertentu dalam waktu yang relatif singkat agar mereka memperoleh pengetahuan, keterampilan, dan sikap yang dapat dimanfaatkan untuk mengembangkan dirinya dan masyarakatnya.

Lembaga pendidikan pelatihan merupakan lembaga pendidikan non-formal yang dapat menyelenggarakan pelatihan keterampilan komputer dalam upaya meningkatkan keterampilan warga masyarakat. Program yang dilaksanakan pada pelatihan komputer, yaitu program komputer dasar (Microsoft Windows, Mengetik 10 Jari), paket aplikasi perkantoran Microsoft Office (Microsoft Word, Microsoft Excel, dan Microsoft Power Point), teknisi komputer (Perakitan dan Troubleshooting Personal Computer), pemrograman Database, Microsoft Access, Dasain Grafis (Macromedia Freehand, CorelDraw, Xara X, dan Adobe Photoshop). Kegiatan ini dilaksanakan secara berkelanjutan dan telah melahirkan lulusan yang berkualitas dan siap menghadapi tantangan global. Pelatihan komputer memberikan kesempatan bagi masyarakat yang ingin mengembangkan pendidikan keterampilannya dalam mengoperasikan komputer yang tidak dapat ditempuh dan tidak terpenuhi pada jalur pendidikan formal. Biasanya dalam pelatihan komputer program Microsoft Office dan Desain Grafis yang sering diajarkan sebagai materi ajar pelaksanaan pelatihan komputer, karena Microsoft Office dan Desain Grafis sering digunakan sebagai pekerjaan diperkantoran. 


\section{METODE}

Penelitian ini menggunakan pendekatan kualitatif. Artinya data yang dikumpulkan bukan berupa angka-angka, melainkan data tersebut berasal dari naskah wawancara, catatan lapangan, dokumen pribadi, catatan memo, dan dokumen resmi lainnya. Oleh karenanya tujuan penelitian yang menggambarkan realita empirik di balik fenomena secara mendalam, rinci dan tuntas dapat tercapai. Penelitian dilakukan di PKBM At-Tajdid yang merupakan salah satu PKBM di Kota Cimahi.

Data penelitian diperoleh dari subjek penelitian sebagai sumber data yang terdiri dari tutor pelatihan komputer, warga belajar, dan pengelola. Yang mengikuti pelatihan komputer di PKBM At-Tajdid Kota Cimahi adalah warga belajar dari paket B dan paket C yang mempunyai kemauan yang tinggi untuk meningkatkan keterampilan komputernya.

Pengumpulan data dilakukan dengan tiga tahap, yaitu tahap orientasi, eksplorasi, dan member chek. Teknik pengumpulan data menggunakan wawancara, observasi, studi dokumentasi, dan angket dalam bentuk instrumen tes mencakup tes tulis, dan tes praktik. Adapun teknik analisis data mencakup reduksi data, data display, dan kesimpulan/verifikasi.

\section{HASIL DAN PEMBAHASAN}

\section{Upaya Peningkatan Life-skills}

\section{Learning to know (belajar untuk memperoleh pengetahuan).}

Learning to know ini adalah tahap awal dari program pelatihan komputer, karena learning to know merupakan kemampuan kognitif (pengetahuan) yang akan didapatkan oleh peserta pelatihan komputer setelah mengikuti pelatihan komputer. Pengetahuan ini berupa teori komputer akan didapatkan oleh peserta pelatihan komputer yaitu Microsoft Word, Microsoft Excel, dan Microsoft Power Point. Berdasarkan hasil wawancara dengan tutor pelatihan komputer, bahwa tutor menyusun teori-teori komputer yang akan diajarkan kepada para peserta pelatihan secara tersusun. yang pertama tutor mengajarkan Microsoft Word, yang kedua Microsoft Excel dan yang terakhir Microsoft Power Point. Dengan tersusunnya teori yang akan diajarkan tutor, dapat memudahkan peserta pelatihan untuk mengingat dan memahaminya, sehingga akan meningkatkan kemampuan kognitif bagi peserta pelatihan. Karena ketiga teori komputer tersebut yang akan diajarkan oleh tutor dalam proses pembelajaran pelatihan komputer. Karena pengetahuan yang akan dimiliki akan penting untuk dapat mempraktikkannya.

\section{Learning to do (belajar untuk dapat berbuat atau bekerja).}

Maksud dari learning to do dalam pembelajaran pelatihan komputer di PKBM At-Tajdid Kota Cimahi adalah teori belajar yang dipilih hendaknya mampu memberikan suatu pekerjaan alternatif kepada peserta pelatihan, oleh karenanya pembelajaran yang sudah diajarkan akan berbuah positif untuk dapat berbuat atau bekerja. Yang diharapkan tutor/intruktur dari proses pembelajaran pelatihan komputer ini adalah peserta pelatihan dapat mengoperasikan komputer serta keluarannya pun dapat bekerja dengan menggunakan keterampilan komputer yang telah dipelajarinya selama mengikuti pelatihan, sehingga peserta tidak sia-sia dalam belajar komputer. Hal ini terungkap dari 
hasil wawancara dengan tutor pelatihan komputer dan beberapa warga belajar peserta pelatihan komputer. Bahwa tutor disini dalam proses pembelajaran pelatihan komputer menggunakan metode pembelajaran yaitu metode ceramah dan metode demonstrasi. Jadi dalam proses belajar mengajar komputer, tutor menjelaskan teori-teori komputer misalnya Microsoft Word dengan ceramah di depan kelas, setelah dijelaskan lalu tutor meminta peserta pelatihan untuk mempraktikkan teori yang sudah dijelaskan dengan menggunakan komputer atau laptop yang sudah disediakan. Jadi dalam tahap ini, peserta pelatihan akan dapat mengoperasikan komputer setelah ia memiliki pengetahuan yang berupa teori komputer yaitu Microsoft Word, Microsoft Excel, dan Microsoft Power Point. Hasil yang didapatkan peserta pelatihan dapat bekerja dengan menggunakan keterampilan komputer yang telah ia kuasai.

\section{Learning to be (belajar untuk menjadi orang yang berguna).}

Pada dasarnya yang diharapkan dari belajar yaitu untuk menjadi orang yang berguna, dengan belajar kita mendapatkan wawasan dan pengetahuan yang luas. Hasil penelitian program pelatihan komputer yang dilaksanakan di PKBM At-Tajdid Kota Cimahi bertujuan meningkatkan keterampilan life-skills warga belajar paket $\mathrm{B}$ dan paket $\mathrm{C}$ khususnya pada bidang komputer. Karena jika warga belajar paket B dan paket C tidak mengikuti keterampilan life-skills, maka setelah lulus nanti warga belajar hanya mendapatkan kemampuan kognitif dan kemampuan afektif saja, yang berupa ijazah dari hasil kelulusan.

Zaman sekarang mencari pekerjaan sangat sulit, bukan hanya pengetahuan saja yang dibutuhkan dalam bekerja, tetapi keterampilan life-skills pun sangat dibutuhkan. Learning to be ini merupakan kecakapan personal yang dimiliki oleh seseorang untuk memiliki kesadaran akan potensi dirinya. Kesadaran akan potensi diri adalah kesadaran yang dimiliki seseorang atas kemampuan dirinya. Dengan kesadaran atas kemampuan diri itu seseorang akan tahu kelebihan dan kekurangannya, kekuatan dan kelemahannya. Dengan kesadaran potensi diri, seseorang akan dapat menempuh kehidupan dengan wajar tanpa merasa tertekan dan mampu memecahkan masalah hidup serta menjadi orang yang berguna bagi dirinya sendiri maupun orang lain. Dengan mengikuti pelatihan komputer, maka setelah lulus nanti warga belajar pun mendapatkan keterampilan skills di bidang komputer, yang akan berguna untuk mendapatkan pekerjaan. Selain memudahkan mendapatkan pekerjaan, warga belajar dapat membuka peluang usaha mandiri seperti bisnis, usaha online, warung internet (warnet) dan sejenis lainnya.

\section{Learning to live together (belajar untuk dapat hidup bersama dengan orang lain).}

Tahap ini pembelajaran tidak hanya cukup diberikan dalam bentuk pengetahuan dan keterampilan saja, tetapi pembelajaran pun diarahkan untuk dapat hidup bersama dengan orang lain. Berdasarkan hasil wawancara dengan tutor, bahwa tutor tidak hanya mengajarkan ketiga teori komputer, tetapi tutor juga memberikan motivasi dan arahan yang benar dan baik kepada warga belajarnya untuk hidup bersama dengan orang lain. Karena manusia tidak akan bisa hidup sendiri tanpa adanya orang lainnya di sekitarnya.

Proses pembelajaran pelatihan komputer di kelas, tutor memberikan motivasi agar tidak pernah malu untuk bertanya. Karena dalam dunia perkerjaan dan usaha persaingan yang ketat dan bagi orang yang memiliki sikap cuek dan malu akan tertinggal. Tutor 
memberikan motivasi kepada peserta pelatihan untuk saling berbaur, menyapa dan membantu, hal tersebut untuk melatih para peserta untuk dapat beradaptasi serta bekerjasama dengan orang lain. Karena dalam dunia kerja dan usaha harus saling bekerjasama dan mampu beradaptasi dengan orang lain.

(Anwar, 2006) selain menyampaikan empat pilar pembelajaran berupa learning to know, learning to do, learning to be, dan learning to live together juga menegaskan ciri-ciri pembelajaran kecakapan hidup, yaitu: a) Terjadi proses identifikasi kebutuhan belajar. b) Terjadinya proses penyadaran untuk belajar bersama. c) Terjadi keselarasan kegiatan belajar untuk mengembangkan diri, belajar, usaha mandiri, dan usaha bersama. d) Terjadi proses pemberian pengalaman dalam melakukan pekerjaan dengan benar, menghasilkan produk bermutu. e) Terjadi proses penguasaan kecakapan personal, sosial, vokasional, akademik, manajerial, dan kewirausahaan. f) Terjadi proses interaksi saling belajar dari para ahli. g) Terjadi proses penilaian kompetensi. h) Terjadinya pendampingan teknik untuk bekerja atau membentuk usaha mandiri. (Anwar, 2006, p. 21)

Program pembelajaran akan memberikan hasil pembelajaran yang berupa pengetahuan (learning to know) untuk dapat mengimplementasikannya. Bahwa tutor mengatakan sebagai tutor pelatihan Meningkatan life-skills warga belajar melalui pelatihan komputer di PKBM At-Tajdid Kota Cimahi harus mampu menempatkan dirinya sebagai fasilitator, disamping itu juga tutor dapat berperan ganda sebagai kawan berdialog bagi peserta pelatihan dalam rangka mengembangkan penguasaan pengetahuan peserta pelatihan.

Teori komputer yang dipilih hendaknya mampu memberikan suatu pekerjaan alternatif kepada peserta pelatihan (learning to do). Dalam proses belajar komputer tidak sekedar untuk menambah pengetahuan peserta, tetapi untuk terampil dalam menguasai ketiga teori komputer yang sudah diajarkan, sehingga menghasilkan sesuatu yang bermakna bagi kehidupannya. Keterampilan merupakan sarana untuk menopang kehidupan seseorang bahkan keterampilan lebih domain dari pada penguasaan pengetahuan semata. Penguasaan pengetahuan dan keterampilan merupakan bagian dari proses menjadi orang yang berguna (learning to be), dengan memiliki keterampilan komputer tersebut maka peserta mampu mendapatkan pekerjaan dan usaha dengan bekal keterampilan komputernya.

Pembelajaran tidak cukup hanya diberikan dalam bentuk keterampilan untuk dirinya sendiri, tetapi juga keterampilan untuk hidup bertetangga, bermasyarakat, berbangsa, dan hidup dalam pergaulan antar bangsa-bangsa dengan semangat kesamaan dan kesejajaran (learning to live together). Dengan kemampuan yang akan dimiliki peserta pelatihan sebagai hasil proses belajar, dapat dijadikan sebagai bekal untuk mampu berperan dalam lingkungan dimana individu tersebut berada, dan sekaligus mampu menempatkan diri sesuai dengan perannya. Pemahaman tentang peran diri dan orang lain dalam kelompok belajar merupakan bekal dalam bersosialisasi di masyarakat.

\section{Hasil Peningkatan Life-Skills}

Hasil wawancara yang dilakukan kepada tutor pelatihan komputer mengenai hasil apa saja yang didapatkan selama mengikuti pelatihan komputer, tutor menjelaskan peserta pelatihan mendapatkan banyak sekali ilmu selama kegiatan pembelajaran berlangsung 
mencakup kemampuan kognitif, afektif, dan psikomotorik (skill). Terkait kemampuan kognitif, sesuai dengan tujuan peserta pelatihan mengikuti pelatihan komputer untuk mendapatkan pengetahuan yang berupa teori komputer yaitu Microsoft Word, Microsoft Excel, dan Microsoft Power Point. Memahami teori tersebut untuk dapat mempraktikkannya dari teori yang telah didapatkan. Pengetahuan mereka bertambah seiring berjalannya kegiatan pelatihan yang diikutinya.

Berdasarkan hasil tes tertulis yang disertai dengan wawancara kepada tutor pelatihan komputer, diperoleh data sebagaimana tabel 1. Kemampuan kognitif berupa nilai yang didapatkan dari tes tertulis dilakukan dengan memberikan format pertanyaan berupa materi-materi yang telah disampaikan lalu dijawab oleh peserta pelatihan komputer.

Kemampuan afektif peserta pelatihan dilihat dari perubahan pada dirinya, yang dibuktikan dengan peserta dapat menyelesaikan tugas-tugas komputer yang diberikan. Dalam praktiknya, peserta mampu mengaplikasikan dan mempraktikkan materi pembelajaran sesuai dengan apa yang telah diajarkan. Dalam hal tersebut menunjukkan kompetensi peserta bertambah meningkat sebelum mengikuti pelatihan komputer.

Program pelatihan komputer di PKBM At-Tajdid Kota Cimahi memberikan bekal pengetahuan dan keterampilan komputer yang terbagi menjadi tiga teori pembelajaran. Teori pembelajaran pertama yang diajarkan oleh tutor adalah Microsoft Word. Setelah peserta dapat memahami serta mempraktikkannya, lalu dilanjutkan dengan pembelajaran yang kedua yaitu Microsoft Excel dan yang terakhir tutor mengajarkan Microsoft Power Point. Pelatihan komputer di PKBM At-Tajdid hanya mengajarkan peserta pelatihan Microsoft Office saja.

(Hamalik, 2003, p. 155), "hasil belajar adalah terjadinya perubahan tingkah laku pada diri seseorang yang dapat diamati dan diukur bentuk pengetahuan, sikap dan keterampilan". Perubahan tersebut dapat diartikan sebagai terjadinya peningkatan dan pengembangan yang tidak tahu menjadi tahu. (Sudjana, 2003) juga mengemukakan bahwa hasil belajar adalah perubahan tingkah laku yang mencakup bidang kognitif, afektif, dan psikomotorik yang dimiliki oleh siswa setelah menerima pengalaman belajar. Demikian yang ditegaskan (Hidayat, 2007), bahwa hasil pelatihan mengindikasi perubahan atau kemampuan warga belajar dari aspek pengetahuan, dan keterampilan serta sikap pengembangan usaha mandiri.

Teori pembelajaran pertama yaitu Microsoft Word, materi yang diajarkan tutor meliputi:

1. Pengenalan tentang software, hardware, dan brainware pada komputer beserta fungsi dan kegunaannya.

2. Mempelajari cara membuka dan menutup Microsoft Word.

3. Mempelajari cara membuka, menyimpan, dan membuat dokumen baru.

4. Mempelajari menu (icon) dan fungsinya yang ada pada Microsoft Word seperti home, insert, page layout, references, mailings, review, dan view.

5. Mempelajari beberapa tombol pintasan pada Microsoft Office, misalnya "CTRL C" (untuk mengkopi), "CTRL X” (untuk memindahkan), "CTRL V” (untuk menyalin) dan lainnya. 
6. Mempelajari cara membuat bagan, tabel, wordart pada Microsoft Word.

7. Mempelajari cara penulisan Microsoft Word secara benar.

Teori pembelajaran kedua yaitu Microsoft Excel, materi yang diajarkan tutor meliputi:

1. Mempelajari menu (icon) dan fungsinya yang ada pada Microsoft Excel.

2. Memepalajari beberapa rumus statistik yang sering digunakan.

3. Mempelajari bagaimana cara menggunakan dan menghitung rumus statistika, seperti: average, min, max, sum, count dan lainnya.

Sedangkan pada teori pembelajaran ketiga yaitu Microsoft Power Point, materi yang diajarkan tutor meliputi:

1. Mempelajari menu (icon) dan fungsinya yang ada pada Microsoft Power Point.

2. Mempelajari cara membuat power point yang baik, dengan mengganti tampilan desain, background, layout, sesuai dengan topik yang akan dibahas.

3. Mempelajari Custom Animation/Effect secara sederhana untuk menambah tampilan slide agar menarik.

4. Mempelajari Design Templates untuk menambah tampilan slide agar menarik.

5. Mempelajari cara membuka, menyimpan dan menutup Microsoft Power Point.

Hasil observasi yang didapatkan, bahwa pelatihan komputer hanya mengajarkan peserta pelatihan Microsoft Word, Microsoft Excel, dan Microsoft Power Point secara sederhana yaitu mempelajari yang sering digunakan saja, yang sukar tidak dipelajari terkecuali atas permintaan peserta. Berdasarkan hasil wawancara dengan tutor pelatihan komputer, bahwa untuk mendapatkan dan mengetahui hasil pelatihan yang berupa keterampilan (skills) komputer peserta pelatihan didapatkan dari instrumen pengumpulan data yang berupa tes praktik. Tes yang dilakukan melalui praktik dilakukan oleh peserta pelatihan sehingga dapat diketahui sejauh mana peserta menguasai materi-materi yang telah disampaikan dan sejauh mana keterampilan komputer yang telah dikuasai. Skills yang didapat dari hasil pelatihan komputer juga berupa nilai yang didapatkan dari tes praktik. Berikut ini adalah hasil tes praktik peserta pelatihan komputer tahun 2016-2017 sebagai pada tabel 2. Hasil pelatihan komputer didapatkan dari instrumen tes yaitu tes tertulis dan tes praktik. Hasilnya yang diperoleh peserta pelatihan menunjukkan sudah dapat memahami, mendapatkan pengetahuan baru, dan mempraktikkannya kembali apa yang sudah mereka dapatkan dari hasil pelatihan. Setelah mengikuti pelatihan komputer di PKBM At-Tajdid peserta mendapatkan pengetahuan, pemahaman, penerapan, dan nilai tentang ketiga teori komputer yang di antarnya Microsoft Word, Microsoft Excel, dan Microsoft Power Point. Bukan hanya pengetahuan yang bertambah, namun keterampilan dan kesiapan untuk bekerja dan usaha juga bertambah. Peserta pelatihan juga mengalami perubahan pada dirinya yang tadinya tidak dapat menguasai komputer dan sekarang menjadi bias menguasai penggunaan komputer. Hasil pelatihan komputer berdaya guna bagi peserta pelatihan untuk diaplikasikan dalam kehidupannya. Setelah semua aspek 
kognitif, afektif, dan skills telah dimiliki tentu akan merubah perspektif dalam kehidupannya, seperti rencana-rencana yang akan dijalankan setelah mengikuti pelatihan.

Tabel 1. Nilai Kognitif Peserta Pelatihan Tahun 2016-2017 (PKBM At-Tajdid Paket B)

\begin{tabular}{|c|c|c|c|c|c|c|}
\hline \multirow{2}{*}{ No } & \multirow{2}{*}{ Nama Peserta } & \multicolumn{3}{|c|}{ Nilai Kognitif Ujian Tertulis } & \multirow{2}{*}{ Rata-Rata Nilai } & \multirow{2}{*}{ Nilai } \\
\cline { 3 - 6 } & & Ms. Word & Ms. Excel & Ms. PPT & & A \\
\hline 1 & Nur Azizah & 80 & 80 & 80 & 80 & $\mathrm{~A}$ \\
\hline 2 & Fatwa Manarul H. & 95 & 85 & 90 & 90 & $\mathrm{~A}$ \\
\hline 3 & Delis Sartika & 85 & 75 & 80 & 80 & $\mathrm{~A}$ \\
\hline 4 & Rudi Fantika & 80 & 75 & 85 & 80 & $\mathrm{~A}$ \\
\hline 5 & Susmilawati & 90 & 90 & 90 & 90 & $\mathrm{~A}$ \\
\hline 6 & Rizky Yohana P. & 95 & 85 & 90 & 90 & $\mathrm{~A}$ \\
\hline 7 & Mirawati & 85 & 85 & 85 & 85 & $\mathrm{~A}$ \\
\hline 8 & Chyntia Kamalia & 90 & 90 & 90 & 90 & $\mathrm{~A}$ \\
\hline 9 & Jimi R. J. S. & 80 & 80 & 80 & 80 & $\mathrm{~A}$ \\
\hline 10 & Elita S. & 85 & 75 & 80 & 80 & \\
\hline
\end{tabular}

Sumber: Data Primer 2017

\begin{tabular}{|c|c|c|c|c|c|c|}
\hline \multirow{2}{*}{ No } & \multirow{2}{*}{ Nama Peserta } & \multicolumn{3}{|c|}{ Nilai Kognitif Ujian Skills } & \multirow{2}{*}{ Rata-Rata Nilai } & \multirow{2}{*}{ Nilai } \\
\cline { 3 - 6 } & & Ms. Word & Ms. Excel & Ms. PPT & & A \\
\hline 1 & Nur Azizah & 85 & 75 & 80 & 80 & $\mathrm{~A}$ \\
\hline 2 & Fatwa Manarul H. & 80 & 80 & 80 & 80 & $\mathrm{~B}$ \\
\hline 3 & Delis Sartika & 80 & 70 & 75 & 75 & $\mathrm{~A}$ \\
\hline 4 & Rudi Fantika & 80 & 80 & 80 & 80 & $\mathrm{~A}$ \\
\hline 5 & Susmilawati & 85 & 75 & 80 & 80 & $\mathrm{~A}$ \\
\hline 6 & Rizky Yohana P. & 90 & 75 & 80 & 80 & $\mathrm{~A}$ \\
\hline 7 & Mirawati & 85 & 80 & 80 & 80 & $\mathrm{~A}$ \\
\hline 8 & Chyntia Kamalia & 85 & 75 & 80 & 80 & $\mathrm{~B}$ \\
\hline 9 & Jimi R. J. S. & 80 & 75 & 75 & 75 & $\mathrm{~B}$ \\
\hline 10 & Elita S. & 85 & 70 & 75 & 75 & \\
\hline
\end{tabular}

Sumber: data Primer 2017

Tabel 2. Nilai Kognitif Peserta Pelatihan Tahun 2016-2017 (PKBM At-Tajdid Paket C)

\begin{tabular}{|c|c|c|c|c|c|c|}
\hline \multirow{2}{*}{ No } & \multirow{2}{*}{ Nama Peserta } & \multicolumn{3}{|c|}{ Nilai Kognitif Ujian Tertulis } & \multirow{2}{*}{ Rata-Rata Nilai } & \multirow{2}{*}{ Nila } \\
\hline & & Ms. Word & Ms. Excel & Ms. PPT & & \\
\hline 1 & Manarul H. W. & 90 & 80 & 85 & 85 & $\mathrm{~A}$ \\
\hline 2 & Wawan Setiawan & 80 & 75 & 85 & 80 & $\mathrm{~A}$ \\
\hline 3 & Enan Supriatna & 90 & 90 & 90 & 90 & $\mathrm{~A}$ \\
\hline 4 & Agus Gaos & 95 & 85 & 90 & 90 & $\mathrm{~A}$ \\
\hline 5 & Apur Purnama & 80 & 75 & 85 & 80 & $\mathrm{~A}$ \\
\hline 6 & Siti Nuraeni & 95 & 85 & 90 & 90 & $\mathrm{~A}$ \\
\hline 7 & S. Trisylana A. A. & 90 & 90 & 90 & 90 & $\mathrm{~A}$ \\
\hline 8 & Dadang Supriatna & 85 & 75 & 80 & 80 & $\mathrm{~A}$ \\
\hline 9 & Imanudin & 80 & 80 & 85 & 80 & $\mathrm{~A}$ \\
\hline 10 & Cecep S. F. & 85 & 85 & 85 & 85 & $\mathrm{~A}$ \\
\hline
\end{tabular}

Sumber: Data Primer 2017 


\begin{tabular}{|c|c|c|c|c|c|c|}
\hline \multirow{2}{*}{ No } & \multirow{2}{*}{ Nama Peserta } & \multicolumn{2}{|c|}{ Nilai Kognitif Ujian Skills } & \multirow{2}{*}{ Rata-Rata Nilai } & \multirow{2}{*}{ Nilai } \\
\cline { 3 - 6 } & & Ms. Word & Ms. Excel & Ms. PPT & & A \\
\hline 1 & Manarul H. W. & 90 & 80 & 85 & 85 & $\mathrm{~B}$ \\
\hline 2 & Wawan Setiawan & 80 & 70 & 75 & 75 & $\mathrm{~A}$ \\
\hline 3 & Enan Supriatna & 90 & 85 & 85 & 85 & $\mathrm{~A}$ \\
\hline 4 & Agus Gaos & 80 & 80 & 80 & 80 & $\mathrm{~A}$ \\
\hline 5 & Apur Purnama & 80 & 80 & 80 & 80 & $\mathrm{~A}$ \\
\hline 6 & Siti Nuraeni & 90 & 75 & 80 & 80 & $\mathrm{~A}$ \\
\hline 7 & S. Trisylana A. A. & 85 & 75 & 80 & 80 & $\mathrm{~B}$ \\
\hline 8 & Dadang Supriatna & 85 & 70 & 75 & 75 & $\mathrm{~B}$ \\
\hline 9 & Imanudin & 80 & 70 & 75 & 75 & $\mathrm{~A}$ \\
\hline 10 & Cecep S. F. & 85 & 75 & 80 & 80 & \\
\hline
\end{tabular}

Sumber: Data Primer 2017

\section{Faktor Pendukung dan Penghambat}

Berdasarkan hasil penelitian, terdapat beberapa faktor pendukung dalam pelaksanaan program pelatihan komputer di PKBM At-Tajdid Kota Cimahi yang mencakup hal mengenai peserta pelatihan, sarana prasarana, biaya, dan keberadaan tutor. Faktor pendukung yang bersumber dari peserta pelatihan yakni tingginya tingkat kemauan untuk meningkatkan keterampilan komputer mereka. Kehadiran serta sikap peserta pun menjadi faktor pendukung dalam meningkatkan keterampilan komputer pada dirinya, karena jika para peserta pelatihan selalu hadir pada jadwal pelatihan yang telah ditetapkan dan peserta pelatihan aktif dalam pembelajaran di kelas, maka peserta pun akan cepat mampu menerima semua pembelajaran yang telah diajarkan sehingga tidak tertinggal.

Sarana fisik seperti gedung dan prasarana seperti jalan menuju ke PKBM At-Tajdid Kota Cimahi sangatlah strategis. Karena PKBM At-Tajdid Kota Cimahi terletak di pinggir jalan, dan media pembelajaran dengan menggunakan modul serta komputer dan laptop yang sangat menunjang. Dalam pelaksanaan program pelatihan komputer di PKBM At-Tajdid Kota Cimahi mendapatkan dana bantuan dari APBD. Bantuan tersebut dipakai untuk transpot tutor, iuran peserta pelatihan, dan sarana belajar seperti komputer, laptop dan modul belajar. Demikian juga tutor pelatihan komputer sangat berkompetensi baik dan mahir dalam bidang komputer khususnya pada Microsoft Office. Hasil penelitian didapatkan beberapa faktor penghambat dalam terlaksananya program pelatihan komputer di PKBM At-Tajdid Kota Cimahi yang juga mencakup hal mengenai peserta pelatihan, sarana prasarana, biaya, dan keberadaan tutor. Dari peserta Pelatihan, masih banyaknya warga belajar paket $\mathrm{B}$ dan paket $\mathrm{C}$ yang tidak ingin meningkatkan keterampilan komputer pada dirinya. Hal ini meskipun sebelum terlaksananya pelatihan komputer di PKBM At-Tajdid Kota Cimahi tutor dan pengelola sudah memberikan motivasi kepada warga belajar untuk mengikuti pelatihan komputer tersebut. Demikian juga tidak adanya peserta pelatihan dari luar atau yang bukan dari warga belajar di PKBM At-Tajdid, karena yang menjadi peserta program pelatihan diambilkan dari peserta kesetaraan paket B dan paket C. Fasilitas komputer sudah cukup baik, tetapi yang menjadi hambatan adalah jumlah komputer pas-pasan dengan peserta pelatihan. Jumlah komputer terdapat 5 unit dan jumlah laptop terdapat 5 unit, sedangkan peserta pelatihan ada 20 orang. (10 Orang Paket B dan 10 Orang Paket C) Jadi satu unit komputer dipakai oleh satu orang peserta pelatihan, maka proses pembelajaran dalam praktik pun kurang nyaman dan tidak 
kondusif karena saling bergantian untuk memakai komputer atau laptop tersebut. Fasilitasi pelatihan komputer mendapatkan bantuan dana dari APBD, tetapi para peserta pelatihan masih diwajibkan untuk membayar sebagian dana sebesar Rp 20.000 untuk proses belajar mengajar. Iuran dana tersebut hanya sekali saja sampai para peserta lulus mengikuti pelatihan komputer. Sebelum mendapatkan bantuan dana dari APBD, para peserta pelatihan komputer dikenakan biaya Rp 100.000. Dari hal itu warga belajar masih banyak yang tidak mau mengikuti pelatihan komputer, karena masih membayar iuran yang diwajibkan. Hal ini membuat kurang tertariknya calon peserta mengikuti program pelatihan. Di samping itu, tutor pelatihan komputer kurang sosialisasi ke luar PKBM, sehingga masyarakat di sekitar lingkungan hanya mengetahuai program yang dilaksanakan PKBM At-Tajdid Kota Cimahi hanya program kesetaraan paket A, paket B, paket C, dan Pendidikan Anak Usia Dini (PAUD) tidak mengetahui adanya program pelatihan komputer. Oleh karenanya, peserta pelatihan komputer hanya dari warga belajar saja yang diambilkan dari peserta program kesetaraan, tidak adanya peserta pelatihan dari luar. Jumlah tutor pelatihan komputer yang hanya berjumlah satu orang sekaligus membuat kelas kurang kondusif. Jika peserta pelatihan banyak yang bertanya, tentunya tutor akan menjadi semakin repot karena harus didampingi praktik secara intens. Demikian pula tutor bukan dari lulusan sarjana komputer ataupun ilmu teknologi informatika. Kondisi demikian seperti yang disampaikan oleh (Laksana, Sholih, \& Naim, 2017), bahwa faktor penghambat pelatihan terdapat pada peserta, kurangnya tenaga pengajar, waktu pelatihan yang diberikan terlalu singkat, dan terbatasnya sarana prasarana.

\section{KESIMPULAN}

Upaya yang dilakukan tutor dalam meningkatkan keterampilan life-skills warga belajar melalui pelatihan komputer sudah sangat baik. Terlihat upaya tutor dalam memberikan bekal pengetahuan yang berupa teori-teori komputer hingga didapatkannya kemampuan peserta pelatihan yang mencakup learning to know, learning to do, learning to be, dan learning to live together. Hasil program pelatihan komputer menjadikan peserta memiliki kemampuan mengaplikasikan dan mempraktikkan dengan benar penggunaan program Microsoft Word, Microsoft Excel, dan Microsoft Power Point. Serta membantu peserta pelatihan dengan mudah mendapat pekerjaan dan usaha. Faktor pendukung mencakup tingginya tingkat kemauan warga belajar untuk mengikuti pelatihan komputer, media pembelajaran yang cukup baik, metode pembelajaran yang baik, serta bantuan dana dari APBD yang cukup membantu. Sedangkan faktor penghambat kurangnya perekturan peserta pelatihan komputer, jumlah komputer yang lebih sedikit dibandingkan jumlah peserta pelatihan, terbatasnya subsidi pemerintah untuk mensubsidi peserta pelatihan, dan jumlah tutor yang hanya satu orang sekaligus bukan lulusan dari bidang komputer. Diharapkan warga belajar yang telah mengikuti pelatihan komputer dapat memanfaatkan keterampilan yang dimilikinya untuk mendapatkan pekerjaan ataupun usaha, dan terus meningkatkan keterampilan komputernya. Kepada pihak pengelola diharapkan dapat terus menambah sarana dan prasarana khususnya dalam program pelatihan komputer, dan adanya penambahan jumlah tutor pelatihan komputer sekaligus keahliannya yang relevan dengan bidangnya serta kemampuan dalam mengajar. 


\section{DAFTAR PUSTAKA}

Anwar, A. (2006). Pendidikan Kecakapan Hidup. Bandung: Alfabeta.

Artasasmita, R. (1985). Pedoman Kursus dan Latihan. Bandung: Jurusan PLS FIP IKIP.

Depdiknas. (2002). Pendekatan Kontekstual (Teaching and Learning). Jakarta: Direktorat Jendral Dasar dan Menengah, Direktorat Pendidikan Lanjutan Pertama, Departemen Pendidikan Nasional.

Hamalik, H. (2003). Proses Belajar Mengajar. Jakarta: Bumi Aksara.

Herlinda, S., Hidayat, S., \& Djumena, I. (2017). Manajemen Pelatihan Hantaran dalam Meningkatan Kecakapan Hidup Warga Belajar di Lembaga Kursus dan Pelatihan. Journal of Non-Formal Education and Community Empowerment, 1-9.

Hidayat, D. (2007). Pengelolaan Pembelajaran Berbasis Kewirausahaan Masyarakat Program Kejar Paket C. 3(1), 1-10.

Laksana, Y., Sholih, S., \& Naim, M. (2017). Pelatihan Tata Rias Pengantin bagi Wanita Tuna Susila dalam Meningkatkan Kemandirian Usaha. Journal of Nonformal Education and Community Empowerment (2), 1(1), 43-54.

Sudjana, D. (2003). Penilaian Hasil Proses Belajar Mengajar. Bandung: Remaja Rosdakarya.

Sudjana, D. (2004). Pendidikan Nonformal: Wawasan, Sejarah Perkembangan, Filsafat, Teori Pendukung, Asas. Bandung: Falah Production. 